\title{
Gender-specific genetic associations of polymorphisms in ACE, AKR1C2, FTO and MMP2 with weight gain over a 10-year period
}

\author{
Freek G. Bouwman · Jolanda M. A. Boer · Sandra Imholz • \\ Ping Wang - W. M. Monique Verschuren • Martijn E. T. Dollé • \\ Edwin C. M. Mariman
}

Received: 9 July 2014/ Accepted: 6 October 2014/Published online: 17 October 2014

(c) Springer-Verlag Berlin Heidelberg 2014

\begin{abstract}
Weight gain, when it leads to overweight or obesity, is nowadays one of the major health problems. ACE, FTO, AKR1C2, TIMP4 and MMP2 genes have been implicated in previous studies on weight regulation. This study investigated the contribution of polymorphisms in these five candidate genes to the risk of weight gain over a 10 -year time period. Two groups were selected from participants of the Doetinchem cohort study who were followed over a 10-year period: A stable weight group ( $\pm 2 \mathrm{~kg} / 10$ year; $n=259$ ) and a weight gainers group who increased their body weight by roughly $10 \%(>8 \mathrm{~kg} /$ 10 year; $n=237$ ). Starting BMI was between 20 and $35 \mathrm{~kg} / \mathrm{m}^{2}$ and baseline age between 20 and 45 years. Selected SNPs and insert/deletion in candidate genes were measured in each group. In men, the allelic distribution of FTO rs9939609 ( $\left.\chi^{2} p=0.005\right)$, ACE $\operatorname{rs4340~}\left(\chi^{2}\right.$ $p=0.006)$ and AKR1C2 rs12249281 ( $\left.\chi^{2} p=0.019\right)$ differed between the weight stable and weight gainers group. Interaction between FTO rs9939609 and ACE rs4340 was observed. In women, the allelic distribution of MMP2 rs1132896 differed between the weight stable and weight gainers group $\left(\chi^{2} p=0.00001\right)$. The A-allele of FTO was
\end{abstract}

Electronic supplementary material The online version of this article (doi:10.1007/s12263-014-0434-2) contains supplementary material, which is available to authorized users.

F. G. Bouwman $(\varangle)$ · P. Wang · E. C. M. Mariman Department of Human Biology, Nutrition and Toxicology Research Institute Maastricht (NUTRIM), Maastricht University, P.O. Box 616, 6200 MD Maastricht, The Netherlands

e-mail: freek.bouwman@maastrichtuniversity.nl

J. M. A. Boer · S. Imholz · W. M. M. Verschuren .

M. E. T. Dollé

National Institute for Public Health and the Environment (RIVM), Bilthoven, The Netherlands associated with a $1.99 \times$ higher risk of gaining weight in men (OR 1.99, $p=0.020$ ), while in women, the C-allele of MMP2 was associated with a $2.50 \times$ higher risk of weight gain (OR 2.50, $p=0.001$ ) over the 10 -year period. We found that FTO in men and MMP2 in women are associated with weight gain over a 10 -year follow-up period.

Keywords Weight gain $\cdot$ Overweight $\cdot$ SNP $\cdot$ Genotyping

\section{Introduction}

Weight gain, when it leads to overweight or obesity, is nowadays one of the major health problems (Wyatt et al. 2006). Unfortunately, the etiology of weight gain is complex and has remained largely unclear. Studies have indicated that lifestyle factors like physical activity, eating behavior and the way to spend leisure time are of influence (Brug et al. 2012). Moreover, body weight seems also to be determined by genetic background, which may be important as an offset of the energy balance as MacLean reported (Maclean et al. 2011).

Several genetic variants have been associated with body weight or weight gain. Polymorphisms in the angiotensin converting enzyme (ACE) gene have been found to be associated with body weight, body mass index (BMI), overweight and obesity (Wang et al. 2012). Recent data suggest that the renin-angiotensin system might be involved in the pathophysiology of obesity and associated hypertension (Darimont et al. 1994). ACE gene polymorphisms influence the levels of plasma ACE, and thereby the level of angiotensin II which is known to play a role in adipocyte growth and the differentiation of preadipocytes to mature adipocytes (Passaro et al. 2011). The best studied ACE gene polymorphism in this respect is the insertion/ 
deletion (I/D) located in intron 16. Additionally, rs9939609 in the gene coding for fat mass and obesity-associated protein (FTO) is a well-known predictor for increased body weight and BMI (Frayling et al. 2007; Scuteri et al. 2007). In adults, individuals with the AA genotype of rs9939609 weigh on average $3 \mathrm{~kg}$ more than those with the TT genotype, and each A-allele increases the BMI with approximately $0.4 \mathrm{~kg} / \mathrm{m}^{2}$ (Frayling et al. 2007). How FTO influences the development of obesity remains unclear, but recent studies suggest that FTO may influence adiposity by affecting appetite (den Hoed et al. 2009). Another suggested mechanism is that obesity-associated SNPs in the intron region of the FTO gene act on body weight via regulation of the expression of IRX3, a homeobox gene playing a role in early neuron development (Ragvin et al. 2010; Smemo et al. 2014). Another candidate gene is the gene for aldo-keto reductase 1C2 (AKR1C2). We have observed correlations between AKR1C2 protein level in adipose tissue and parameters of adiposity (Bouwman et al. 2009). It has also been reported that the level of AKR1C2 mRNA expression in adipose tissue of women positively correlates with adiposity (Blouin et al. 2005). Similarly, Wake et al. (2007) showed that central fat distribution, measured by waist/hip ratio, was associated with mRNA expression for AKR1C2 in white adipose tissue.

An association has also been found between obesity and genetic variation in the gene for matrix metalloproteinase-2 (MMP2) (Han et al. 2008), of which the activity is controlled by tissue inhibitor of metalloproteinase 4 (TIMP4). MMP2 and TIMP4 are proteins involved in the remodeling of the extracellular matrix (ECM) of adipocytes, which is essential for the development of adipocytes (Bouloumie et al. 2001). An imbalance between MMP2 and TIMP4 could have an effect on ECM remodeling and as such on fat mass development (Chavey et al. 2003).

The aim of the present study was to investigate if preselected genetic polymorphisms in these candidate genes influence weight gain over a 10 -year period of time.

\section{Materials and methods}

\section{Study population}

The present study selected subjects from the ongoing Doetinchem cohort ( $\mathrm{Lu}$ et al. 2008; van den Berg et al. 2009). The design of the Doetinchem study and detailed methods have been reported earlier (Verschuren et al. 2008). Participants were eligible for the present study if he/ she has participated in three consecutive rounds of examinations covering a 10-year period, were stable in smoking habits and not pregnant, starting BMI between 20 and $35 \mathrm{~kg} / \mathrm{m}^{2}$, and baseline age between 20 and 45 years

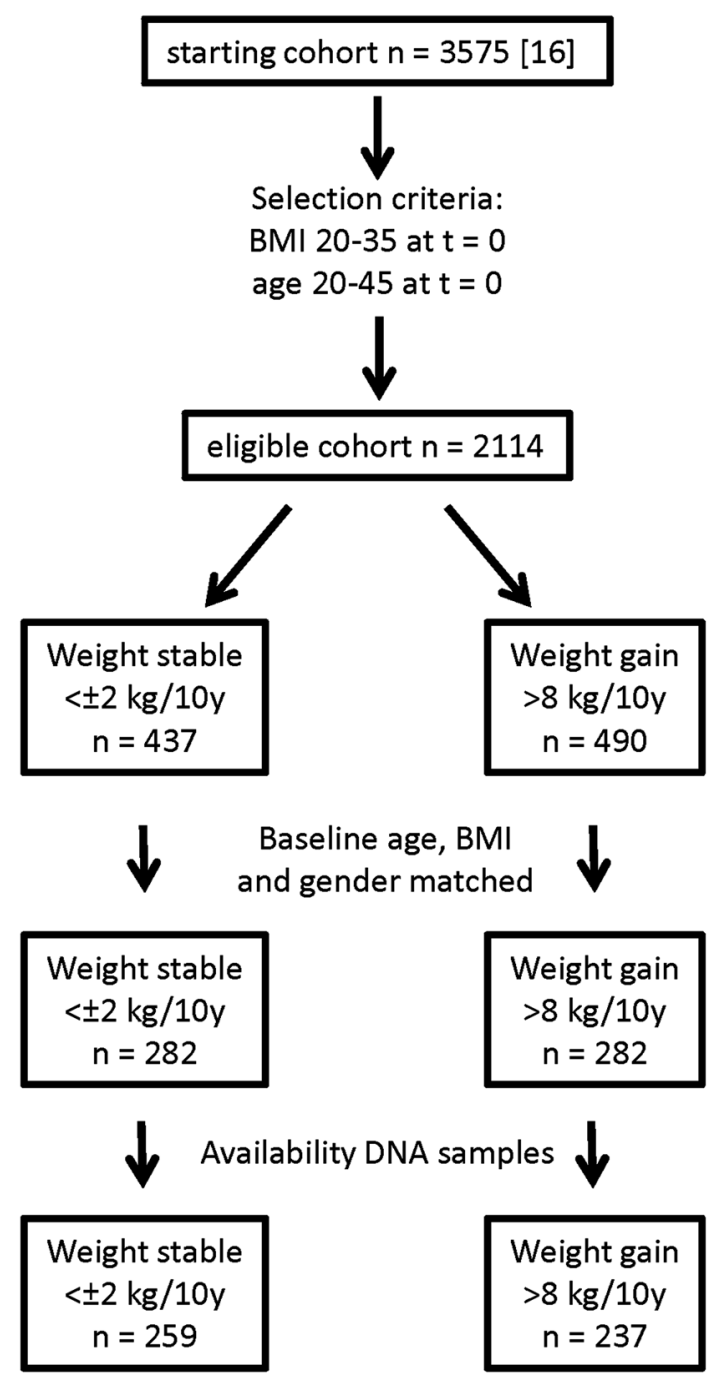

Fig. 1 Flowchart of the different selection steps and the number of participants

(Fig. 1). Based on a relative risk of two, a power calculation indicated that 208 subjects in each group are required for a power of 0.8 . We selected a stable weight group $(< \pm 2 \mathrm{~kg} / 10$ year) and a weight gainers group $(>8 \mathrm{~kg} /$ 10 year) from these eligible subjects. The two groups were group-matched for baseline age, BMI and gender, resulting in 282 participants per group. In the stable weight group, 259 DNA samples of the participants were available and in the weight gainers group, 237 DNA samples of the participants (Fig. 1). The $8 \mathrm{~kg}$ weight gain is roughly $10 \%$ of the initial body weight. The study was approved by the external Medical Ethics Committee (MEC) of the Netherlands Organization of Applied Scientific Research according to the guidelines of the Declaration of Helsinki. A written informed consent, approved by the MEC, was obtained from all participants. At the start of the study, a blood sample was drawn, fractionated to obtain buffy coats for isolation of DNA and subsequently stored at $-30^{\circ} \mathrm{C}$. 
DNA isolation, SNP selection and genotyping

Genomic DNA was isolated from stored buffy coats using a salting out method as described before (van den Berg et al. 2009). To ensure a considerable fraction of carriers of the minor allele, only SNPs with a minor allele frequency in Europeans of at least $25 \%$, as indicated in the SNP public database (dbSNP; http://www.ncbi.nlm.nih.gov/SNP), were considered as candidates. Preferably, SNPs were considered that had earlier been shown to be associated with relevant phenotypes, such as BMI or body composition. Polymorphisms in angiotensin converting enzyme (ACE), fat mass and obesity-associated protein (FTO), aldo-keto reductase $1 \mathrm{C} 2$ (AKR1C2), tissue inhibitor of metalloproteinase 4 (TIMP4) and matrix metalloproteinase-2 (MMP2) were chosen as candidate genes for weight gain, also based on previous research (Bouwman et al. 2009; Wang et al. 2012). Genotyping was performed using commercially available TaqMan SNP genotyping assays from Applied Biosystems (Foster City, CA, USA). The procedure was performed according to the manufacturer's protocol and measured on an Applied Biosystems 7900 HT fast real-time PCR system. Allelic calls were determined semiautomatically using the SDS 2.3 software. The ACE deletion/insertion (rs4340) was determined with the following primers: Forward primer $5^{\prime}$-CCTTTCTCCCATTT CTCTAGACCTG-3' DEL-Reverse Primer 5'-GCTCAGA GAATTTCAGAGCTGGA-3' INS-Reverse Primer 5'-GAT CCCGCCACTGCACTC-3' DEL-Probe 5'-VIC-TGCCT ATACAGTCACTTTTATGTGGTTTCGC-TAMRA-3' ${ }^{\prime}$ and INS-Probe 5'-FAM-CTCGCTCTGTCGCCCAGGCTTAMRA-3'. The PCR was performed using the following PCR program: denaturation $10 \mathrm{~min}$ at $95{ }^{\circ} \mathrm{C}$ followed by 40 cycles of denaturation at $95^{\circ} \mathrm{C}$ for $15 \mathrm{~s}$ and annealing/ extension at $62{ }^{\circ} \mathrm{C}$ for $1 \mathrm{~min}$ (Koh et al. 2003). The allelic calls were determined semiautomatically using the SDS 2.3 software.

\section{Statistical analysis}

Hardy-Weinberg equilibrium (HWE) for the different polymorphisms was calculated using the Chi square test. Linkage disequilibrium (LD) was calculated using SNAP which is a web-based tool for identification and annotation of SNPs in LD using HapMap 3 (release 2) (Johnson et al. 2008). SNAP is publicly available at http://www.broad.mit. edu/mpg/snap. We used Pearson's Chi square test to examine differences in the frequencies of the genotypes between the weight stable and weight gainers group. The inheritance model with the most significant $p$ value was chosen using the SNPStats program (Sole et al. 2006). SNPStats is publicly available at http://bioinfo.iconcologia.
Table 1 Characteristics of the study population

\begin{tabular}{|c|c|c|c|c|}
\hline & \multicolumn{2}{|l|}{ Men } & \multicolumn{2}{|l|}{ Women } \\
\hline & $\begin{array}{l}\text { Weight } \\
\text { stable }\end{array}$ & $\begin{array}{l}\text { Weight } \\
\text { gainers }\end{array}$ & $\begin{array}{l}\text { Weight } \\
\text { stable }\end{array}$ & $\begin{array}{l}\text { Weight } \\
\text { gainers }\end{array}$ \\
\hline $\begin{array}{l}\text { Number of } \\
\text { subjects }\end{array}$ & 132 & 120 & 127 & 117 \\
\hline \multicolumn{5}{|l|}{ Baseline } \\
\hline Age (years) & $35.2 \pm 6.1$ & $36.0 \pm 5.6$ & $35.4 \pm 5.6$ & $36.0 \pm 5.6$ \\
\hline Weight (kg) & $79.0 \pm 8.6$ & $80.5 \pm 8.7$ & $67.3 \pm 8.0$ & $68.5 \pm 8.0$ \\
\hline BMI $\left(\mathrm{kg} / \mathrm{m}^{2}\right)$ & $24.1 \pm 2.2$ & $24.4 \pm 2.5$ & $23.8 \pm 2.7$ & $24.1 \pm 2.6$ \\
\hline \multicolumn{5}{|l|}{ Follow-up } \\
\hline $\begin{array}{l}\text { Follow-up time } \\
\text { (years) }\end{array}$ & $10.9 \pm 0.2$ & $10.9 \pm 0.2$ & $10.9 \pm 0.2$ & $10.9 \pm 0.2$ \\
\hline Weight $(\mathrm{kg})$ & $79.7 \pm 8.6$ & $92.4 \pm 9.3$ & $67.6 \pm 7.8$ & $81.7 \pm 9.2$ \\
\hline $\begin{array}{l}\text { Weight gain } \\
\text { (kg/10 years) }\end{array}$ & $0.7 \pm 1.1$ & $11.8 \pm 2.8$ & $0.3 \pm 1.2$ & $13.2 \pm 4.2$ \\
\hline BMI $\left(\mathrm{kg} / \mathrm{m}^{2}\right)$ & $24.3 \pm 2.2$ & $27.9 \pm 2.8$ & $23.9 \pm 2.7$ & $28.8 \pm 3.2$ \\
\hline
\end{tabular}

Results are presented as mean \pm SD

net/snpstats. All statistical analyses were performed for men and women separately and adjusted for matching criteria, i.e., baseline age and baseline BMI. Logistic regression was performed using the logit function in generalized linear model to examine the effect of the polymorphisms on weight gain, using baseline age and BMI as covariates. Pearson's Chi square test and logistic regression analyses were done using the SPSS v20.0 statistical software. To identify epistatic interactions, the multifactor dimensionality reduction (MDR) method was used (Heidema et al. 2007). The MDR software is publicly available at http://www.epistasis.org. A $p$ value $<0.05$ was considered statistically significant. To evaluate the gene-dietary interaction, the cohort was stratified to low, medium and high intake level for each dietary factor in each sex group. Logistic regression was used to examine the effect of the interaction between allelic type and dietary intake level for weight gain on each dietary factor and each SNP. To correct for multiple testing, Bonferroni correction was applied, a significance threshold of $p$ value $=0.007$ was used in the Chi square test for examining the relation between seven SNPs and weight gain.

\section{Results}

\section{Subject characteristics}

On average, weight gainers increased their body weight with $11.8 \mathrm{~kg}$ in men and $13.2 \mathrm{~kg}$ in women. This was roughly $10 \%$ or more of their baseline weight and resulted in a 3.6 and $4.9 \mathrm{~kg} / \mathrm{m}^{2}$ increase in BMI, respectively (Table 1). Information on dietary intake is given in Table 2. In women, carbohydrate and protein intake 
differed between the weight stable and weight gainers group. No differences were observed in men.

Genetic analysis

The genotypic and allelic distributions of the determined polymorphisms are shown in Table 3. All SNPs were in Hardy-Weinberg equilibrium. None of the SNPs were in linkage disequilibrium (LD), indicating that all SNPs

Table 2 Average dietary intake in men and women over the 10-year follow-up period

\begin{tabular}{|c|c|c|c|c|}
\hline & \multicolumn{2}{|l|}{ Men } & \multicolumn{2}{|l|}{ Women } \\
\hline & $\begin{array}{l}\text { Weight } \\
\text { stable } \\
n=132\end{array}$ & $\begin{array}{l}\text { Weight } \\
\text { gainers } \\
n=120\end{array}$ & $\begin{array}{l}\text { Weight } \\
\text { stable } \\
n=127\end{array}$ & $\begin{array}{l}\text { Weight } \\
\text { gainers } \\
n=117\end{array}$ \\
\hline $\begin{array}{l}\text { Energy intake } \\
\text { (MJ/day) }\end{array}$ & $11.1 \pm 2.5$ & $10.6 \pm 2.1$ & $8.0 \pm 1.6$ & $8.4 \pm 1.7$ \\
\hline Fat (g/day) & $107 \pm 27$ & $101 \pm 24$ & $77 \pm 19$ & $81 \pm 22$ \\
\hline $\begin{array}{l}\text { Carbohydrate } \\
\text { (g/day) }\end{array}$ & $297 \pm 72$ & $282 \pm 65$ & $215 \pm 50^{*}$ & $231 \pm 53^{*}$ \\
\hline Protein (g/day) & $97 \pm 20$ & $94 \pm 18$ & $74 \pm 14^{*}$ & $78 \pm 14 *$ \\
\hline
\end{tabular}

Values are presented as mean $\pm \mathrm{SD}$

$* p<0.05$ between weight groups provided independent information and thus can be used separately for further statistics.

\section{ACE deletion/insertion rs4340}

The distribution of the genotypes between the weight stable and weight gainers group was significantly different $(p=0.006)$ in men, but not in women $(p=0.84$, Table 4$)$. Although borderline statistically significant when using a recessive model, that fitted best, the I/I genotype increased the risk of weight gain over the 10 years in men [OR 1.91, $95 \%$ CI (0.93-3.93), Table 5].

\section{FTO rs9939609}

The A-allele of this SNP was associated with weight gain in men, but not in women. The A-allele frequency was significantly higher in the weight gainers than in the weight stable group ( 0.45 vs $0.35, p=0.001$, Table 4 ). Also, the genotype distribution differed between the weight gainers and weight stable group $\left(\chi^{2} p=0.005\right)$. Logistic regression analysis shows that the combined $\mathrm{A} / \mathrm{A}$ and $\mathrm{A} / \mathrm{T}$ genotypes of FTO in men were associated with weight gain (Table 5). Being a male A-allele carrier increased the risk of gaining weight over the 10 -year period by 1.99 -fold (95\% CI 1.16-3.39, Table 5).
Table 3 Genotype and allele frequencies per polymorphism in the whole study population

\begin{tabular}{|c|c|c|c|c|c|c|c|}
\hline Gene & Polymorphism & Genotypes & $n$ & $F(\%)$ & Allele & $F(\%)$ & $\mathrm{HWE}^{\mathrm{a}}$ \\
\hline \multirow[t]{3}{*}{ ACE } & \multirow[t]{3}{*}{ rs4340 } & Del/Del & 141 & 28.4 & Del & 55.1 & \multirow[t]{3}{*}{0.10} \\
\hline & & Del/Ins & 263 & 53.0 & Ins & 44.9 & \\
\hline & & Ins/Ins & 91 & 18.3 & & & \\
\hline \multirow[t]{3}{*}{ FTO } & \multirow[t]{3}{*}{ rs9939609 } & $\mathrm{A} / \mathrm{A}$ & 78 & 15.7 & A & 38.0 & \multirow[t]{3}{*}{0.14} \\
\hline & & $\mathrm{A} / \mathrm{T}$ & 214 & 43.1 & $\mathrm{~T}$ & 62.0 & \\
\hline & & $\mathrm{T} / \mathrm{T}$ & 195 & 39.3 & & & \\
\hline \multirow[t]{3}{*}{ AKR1C2 } & rs 2854482 & $\mathrm{~A} / \mathrm{A}$ & 457 & 92.1 & A & 96.1 & \multirow[t]{3}{*}{0.36} \\
\hline & \multirow[t]{2}{*}{ F46Y } & $\mathrm{A} / \mathrm{T}$ & 39 & 7.9 & \multirow[t]{2}{*}{$\mathrm{T}$} & \multirow[t]{2}{*}{3.9} & \\
\hline & & $\mathrm{T} / \mathrm{T}$ & 0 & 0 & & & \\
\hline AKR1C2 & \multirow[t]{3}{*}{ rs4143631 } & $\mathrm{C} / \mathrm{C}$ & 258 & 52.0 & $\mathrm{C}$ & 71.2 & \multirow[t]{3}{*}{0.20} \\
\hline \multirow[t]{2}{*}{ Promoter } & & $\mathrm{C} / \mathrm{T}$ & 191 & 38.5 & $\mathrm{~T}$ & 28.8 & \\
\hline & & $\mathrm{T} / \mathrm{T}$ & 47 & 9.5 & & & \\
\hline AKR1C2 & \multirow[t]{3}{*}{ rs12249281 } & $\mathrm{A} / \mathrm{A}$ & 129 & 26.0 & A & 48.9 & \multirow[t]{3}{*}{0.07} \\
\hline \multirow[t]{2}{*}{ Promoter } & & $\mathrm{A} / \mathrm{G}$ & 227 & 45.8 & G & 51.1 & \\
\hline & & $\mathrm{G} / \mathrm{G}$ & 140 & 28.2 & & & \\
\hline \multirow[t]{3}{*}{ TIMP4 } & \multirow[t]{3}{*}{ rs3755724 } & $\mathrm{C} / \mathrm{C}$ & 219 & 44.2 & $\mathrm{C}$ & 66.4 & \multirow[t]{3}{*}{0.84} \\
\hline & & $\mathrm{C} / \mathrm{T}$ & 219 & 44.2 & $\mathrm{~T}$ & 33.6 & \\
\hline & & $\mathrm{T} / \mathrm{T}$ & 57 & 11.5 & & & \\
\hline \multirow[t]{3}{*}{ MMP2 } & \multirow[t]{3}{*}{ rs1132896 } & $\mathrm{C} / \mathrm{C}$ & 60 & 12.1 & $\mathrm{C}$ & 35.6 & \multirow[t]{3}{*}{0.63} \\
\hline & & $\mathrm{C} / \mathrm{G}$ & 231 & 46.6 & G & 64.4 & \\
\hline & & $\mathrm{G} / \mathrm{G}$ & 202 & 40.7 & & & \\
\hline
\end{tabular}


Table 4 Relationship between frequency of the different polymorphisms and weight gain over a 10-year period

\begin{tabular}{|c|c|c|c|c|c|c|c|}
\hline \multirow[t]{2}{*}{ SNP } & \multirow[t]{2}{*}{ Genotype or allele } & \multicolumn{3}{|l|}{ Men } & \multicolumn{3}{|l|}{ Women } \\
\hline & & Stable weight & Weight gainers & $\chi^{2} p$ value & Stable weight & Weight gainers & $\chi^{2} p$ value \\
\hline ACE & $\mathrm{D} / \mathrm{D}$ & $37(28 \%)$ & $36(30 \%)$ & $0.006^{*}$ & $34(27 \%)$ & $34(29 \%)$ & 0.837 \\
\hline \multirow[t]{4}{*}{ rs4340 } & $\mathrm{D} / \mathrm{I}$ & $80(61 \%)$ & $61(51 \%)$ & & $64(50 \%)$ & $58(50 \%)$ & \\
\hline & $\mathrm{I} / \mathrm{I}$ & $14(11 \%)$ & $23(19 \%)$ & & $29(23 \%)$ & $25(21 \%)$ & \\
\hline & $\mathrm{D}$ & 0.59 & 0.55 & 0.290 & 0.52 & 0.54 & 0.318 \\
\hline & I & 0.41 & 0.45 & & 0.48 & 0.46 & \\
\hline FTO & $\mathrm{A} / \mathrm{A}$ & $18(14 \%)$ & $24(20 \%)$ & $0.005^{*}$ & $17(13 \%)$ & $19(17 \%)$ & 0.520 \\
\hline \multirow[t]{4}{*}{ rs9939609 } & $\mathrm{A} / \mathrm{T}$ & $53(42 \%)$ & $59(50 \%)$ & & $56(44 \%)$ & $46(40 \%)$ & \\
\hline & $\mathrm{T} / \mathrm{T}$ & $56(44 \%)$ & $35(30 \%)$ & & $54(43 \%)$ & $50(43 \%)$ & \\
\hline & A & 0.35 & 0.45 & $0.001^{*}$ & 0.35 & 0.37 & 0.730 \\
\hline & $\mathrm{T}$ & 0.65 & 0.55 & & 0.65 & 0.63 & \\
\hline $\mathrm{AKR} 1 \mathrm{C} 2$ & $\mathrm{~A} / \mathrm{A}$ & $120(91 \%)$ & $110(92 \%)$ & 0.773 & $118(93 \%)$ & $109(93 \%)$ & 0.916 \\
\hline \multirow[t]{4}{*}{ rs2854482 } & $\mathrm{A} / \mathrm{T}$ & $12(9 \%)$ & $10(8 \%)$ & & $9(7 \%)$ & $8(7 \%)$ & \\
\hline & $\mathrm{T} / \mathrm{T}$ & $0(0 \%)$ & $0(0 \%)$ & & $0(0 \%)$ & $0(0 \%)$ & \\
\hline & A & 0.95 & 0.96 & 0.778 & 0.96 & 0.97 & 0.918 \\
\hline & $\mathrm{T}$ & 0.05 & 0.04 & & 0.04 & 0.03 & \\
\hline AKR1C2 & $\mathrm{C} / \mathrm{C}$ & $69(52 \%)$ & $60(50 \%)$ & 0.580 & $67(53 \%)$ & $62(53 \%)$ & 0.792 \\
\hline \multirow[t]{4}{*}{ rs4143631 } & $\mathrm{C} / \mathrm{T}$ & $54(41 \%)$ & $49(41 \%)$ & & $47(37 \%)$ & $41(35 \%)$ & \\
\hline & $\mathrm{T} / \mathrm{T}$ & $9(7 \%)$ & $11(9 \%)$ & & $13(10 \%)$ & $14(12 \%)$ & \\
\hline & $\mathrm{C}$ & 0.73 & 0.70 & 0.422 & 0.71 & 0.71 & 0.801 \\
\hline & $\mathrm{T}$ & 0.28 & 0.30 & & 0.29 & 0.29 & \\
\hline AKR1C2 & $\mathrm{A} / \mathrm{A}$ & $27(20 \%)$ & $35(29 \%)$ & 0.019 & $35(28 \%)$ & $32(27 \%)$ & 0.955 \\
\hline \multirow[t]{4}{*}{ rs12249281 } & $\mathrm{A} / \mathrm{G}$ & $68(52 \%)$ & $48(40 \%)$ & & $57(44 \%)$ & $54(46 \%)$ & \\
\hline & $\mathrm{G} / \mathrm{G}$ & $37(28 \%)$ & $37(31 \%)$ & & $35(28 \%)$ & $31(26 \%)$ & \\
\hline & A & 0.46 & 0.49 & 0.359 & 0.5 & 0.5 & 0.896 \\
\hline & G & 0.54 & 0.51 & & 0.5 & 0.5 & \\
\hline TIMP4 & $\mathrm{C} / \mathrm{C}$ & $61(46 \%)$ & $49(41 \%)$ & 0.532 & $56(44 \%)$ & $53(45 \%)$ & 0.941 \\
\hline \multirow[t]{4}{*}{ rs 3755724} & $\mathrm{C} / \mathrm{T}$ & $54(41 \%)$ & $54(45 \%)$ & & $58(46 \%)$ & $53(45 \%)$ & \\
\hline & $\mathrm{T} / \mathrm{T}$ & $17(13 \%)$ & $16(13 \%)$ & & $13(10 \%)$ & $11(9 \%)$ & \\
\hline & $\mathrm{C}$ & 0.67 & 0.64 & 0.315 & 0.67 & 0.68 & 0.740 \\
\hline & $\mathrm{T}$ & 0.33 & 0.36 & & 0.33 & 0.32 & \\
\hline MMP2 & $\mathrm{C} / \mathrm{C}$ & $14(11 \%)$ & $18(15 \%)$ & 0.146 & $16(13 \%)$ & $12(10 \%)$ & $0.000 *$ \\
\hline \multirow[t]{4}{*}{ rs1132896 } & $\mathrm{C} / \mathrm{G}$ & $58(44 \%)$ & $44(37 \%)$ & & $54(43 \%)$ & $75(65 \%)$ & \\
\hline & $\mathrm{G} / \mathrm{G}$ & $59(45 \%)$ & $57(48 \%)$ & & $57(45 \%)$ & $29(25 \%)$ & \\
\hline & $\mathrm{C}$ & 0.33 & 0.34 & 0.795 & 0.34 & 0.43 & $0.005^{*}$ \\
\hline & G & 0.67 & 0.66 & & 0.66 & 0.57 & \\
\hline
\end{tabular}

* Significant after multiple testing $p<0.007$

AKR1C2 rs2854482, rs4143631 and rs12249281. rs2854482 is until now the only known functional SNP in the NCBI database of AKR1C2. This amino acid variation has an effect on the enzyme activity and on cofactor binding (Arthur and Reichardt 2010). The A-allele exchanges the amino acid $\mathrm{F}$ into $\mathrm{Y}$, which decreases the enzyme activity. rs4143631 is in the promoter inside the CNV region, while rs12249281 is in the promoter but outside the $\mathrm{CNV}$ region. Figure 2 shows a schematic overview of the relative position of the AKR1C2 gene, the
$\mathrm{CNV}$ and the investigated SNPs. The T/T homozygote of rs2854482 was not present in our study population (Table 4). For this SNP as well as for rs4143631, no significant differences in the genotype and allele frequencies between the weight stable and weight gainer groups were observed. In contrast, in men, the A/A genotype of rs12249281 was more frequent and the $\mathrm{A} / \mathrm{G}$ genotype less frequent among weight gainers than among the weight stable group $\left(\chi^{2} p=0.019\right.$ Table 4$)$. However, linear regression based on a recessive model did not show 
Table 5 Results of logistic regression analysis with weight gain as dependent variable (stable weight is reference) and the genotypes as independent variable adjusted for baseline age and BMI

\begin{tabular}{|c|c|c|c|c|c|c|c|c|c|c|}
\hline \multirow[t]{2}{*}{ Gene } & \multirow[t]{2}{*}{ rs number } & \multirow{2}{*}{$\begin{array}{l}\text { Genotype/ } \\
\text { model }\end{array}$} & \multicolumn{4}{|l|}{ Men } & \multicolumn{4}{|l|}{ Women } \\
\hline & & & $\begin{array}{l}\text { Stable } \\
\text { weight }(n)\end{array}$ & $\begin{array}{l}\text { Weight } \\
\text { gainers }(n)\end{array}$ & $\begin{array}{l}\text { Odds ratio } \\
(95 \% \mathrm{CI})\end{array}$ & $p$ & $\begin{array}{l}\text { Stable } \\
\text { weight }(n)\end{array}$ & $\begin{array}{l}\text { Weight } \\
\text { gainers }(n)\end{array}$ & $\begin{array}{l}\text { Odds ratio } \\
(95 \% \mathrm{CI})\end{array}$ & $p$ \\
\hline \multirow[t]{2}{*}{ ACE } & rs 4340 & $\mathrm{I} / \mathrm{I}$ versus & 14 & 23 & $\begin{array}{l}1.91 \\
\quad(0.93-3.93)\end{array}$ & 0.077 & 29 & 25 & $\begin{array}{l}0.94 \\
\quad(0.51-1.72)\end{array}$ & 0.831 \\
\hline & & $\mathrm{D} / \mathrm{D}-\mathrm{D} / \mathrm{I}^{\mathrm{b}}$ & 117 & 97 & & & 98 & 92 & & \\
\hline \multirow[t]{2}{*}{ FTO } & rs9939609 & $\begin{array}{c}\mathrm{A} / \mathrm{A}-\mathrm{A} / \mathrm{T} \\
\text { versus }\end{array}$ & 71 & 83 & $\begin{array}{l}1.99 \\
(1.16-3.39)\end{array}$ & $0.012^{*}$ & 73 & 65 & $\begin{array}{l}0.95 \\
\quad(0.57-1.58)\end{array}$ & 0.845 \\
\hline & & $\mathrm{T} / \mathrm{T}^{\mathrm{a}}$ & 56 & 35 & & & 54 & 50 & & \\
\hline \multirow[t]{2}{*}{ AKR1C2 } & rs2854482 & $\begin{array}{l}\mathrm{A} / \mathrm{A} \\
\text { versus }\end{array}$ & 120 & 110 & $\begin{array}{l}1.17 \\
\quad(0.48-2.85)\end{array}$ & 0.722 & 118 & 109 & $\begin{array}{l}1.03 \\
(0.38-2.77)\end{array}$ & 0.960 \\
\hline & & $\mathrm{A} / \mathrm{T}^{\mathrm{c}}$ & 12 & 10 & & & 9 & 8 & & \\
\hline \multirow[t]{2}{*}{ AKR1C2 } & rs4143631 & $\mathrm{T} / \mathrm{T}$ versus & 9 & 11 & $\begin{array}{l}1.47 \\
(0.58-3.72)\end{array}$ & 0.412 & 13 & 14 & $\begin{array}{l}1.15 \\
(0.51-2.58)\end{array}$ & 0.736 \\
\hline & & $\mathrm{C} / \mathrm{C}-\mathrm{C} / \mathrm{T}^{\mathrm{b}}$ & 123 & 109 & & & 114 & 103 & & \\
\hline \multirow[t]{2}{*}{ AKR1C2 } & rs12249281 & $\begin{array}{l}\mathrm{A} / \mathrm{A} \\
\text { versus }\end{array}$ & 27 & 35 & $\begin{array}{l}1.57 \\
(0.88-2.82)\end{array}$ & 0.128 & 35 & 32 & $\begin{array}{l}0.97 \\
\quad(0.55-1.71)\end{array}$ & 0.909 \\
\hline & & $\mathrm{G} / \mathrm{G}-\mathrm{G} / \mathrm{A}^{\mathrm{b}}$ & 105 & 85 & & & 92 & 85 & & \\
\hline \multirow[t]{2}{*}{ TIMP4 } & rs3755724 & $\begin{array}{c}\mathrm{T} / \mathrm{T}-\mathrm{T} / \mathrm{C} \\
\text { versus }\end{array}$ & 61 & 49 & $\begin{array}{l}1.28 \\
(0.77-2.14)\end{array}$ & 0.345 & 71 & 64 & $\begin{array}{l}0.97 \\
\quad(0.58-1.61)\end{array}$ & 0.909 \\
\hline & & $\mathrm{C} / \mathrm{C}^{\mathrm{a}}$ & 71 & 70 & & & 56 & 53 & & \\
\hline \multirow[t]{2}{*}{ MMP2 } & rs1132896 & $\begin{array}{c}\mathrm{C} / \mathrm{C}-\mathrm{C} / \mathrm{G} \\
\text { versus }\end{array}$ & 72 & 62 & $\begin{array}{l}0.90 \\
\quad(0.55-1.50)\end{array}$ & 0.693 & 70 & 87 & $\begin{array}{l}2.50 \\
\quad(1.44-4.35)\end{array}$ & $0.001 *$ \\
\hline & & $\mathrm{G} / \mathrm{G}^{\mathrm{a}}$ & 59 & 57 & & & 57 & 29 & & \\
\hline
\end{tabular}

* indicates significant value $p<0.05$

${ }^{\mathrm{a}}$ Dominant, ${ }^{\mathrm{b}}$ recessive, ${ }^{\mathrm{c}}$ codominant

Fig. 2 Schematic overview of the position of the AKR1C2 gene, the $\mathrm{CNV}$ region (copy number variation) and the investigated SNPs

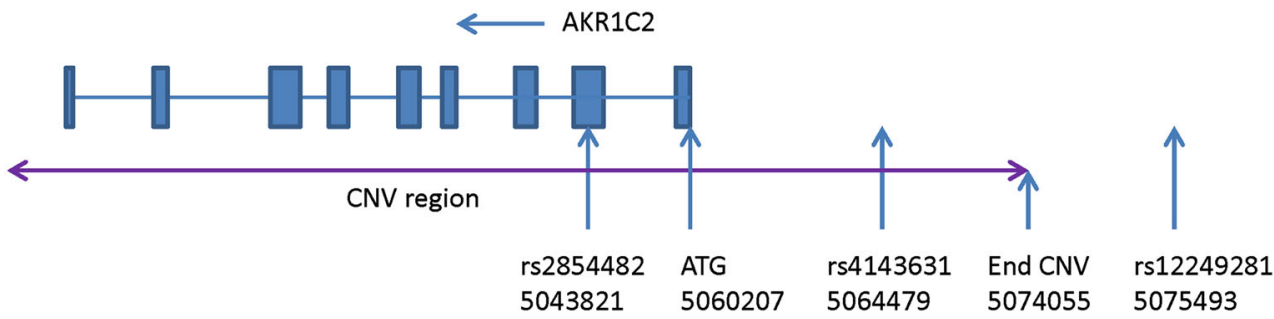

significant results (Table 5). In women, no association with any of the AKR1C2 genotypes was observed.

\section{TIMP4 rs3755724}

In both men and women, no significant differences were found in the genotype or allele frequencies between the weight stable and weight gainers group (Table 4).

MMP2 rs 1132896

Significantly, different allele frequencies were observed between the female weight stable and weight gainers group with the $\mathrm{C}$-allele being more frequent among the weight gainers (43 vs $34 \%, p=0.005$, Table 4). Also, the genotype distribution between the weight stable and gainers differed $\left(\chi^{2}\right.$ $p=0.00001)$. The frequency of the $\mathrm{C} / \mathrm{G}$ genotype was higher in the weight gainers $(65 \%)$ than in the weight stable group (43\%). The G/G genotype was lower (25 vs $45 \%$, Table 4 ). Logistic regression analysis showed being a carrier of the C-allele of MMP2 in women conferred a 2.50-fold (95\% CI 1.44-4.35) higher risk for weight gain over a 10-year period than being a carrier of the G/G genotype (Table 5). No significant differences between weight gainers and the weight stable group were observed for men.

SNP-SNP interactions

MDR analysis revealed a significant SNP-SNP interaction for weight gain between FTO and ACE in men (Fig. 3). Logistic 


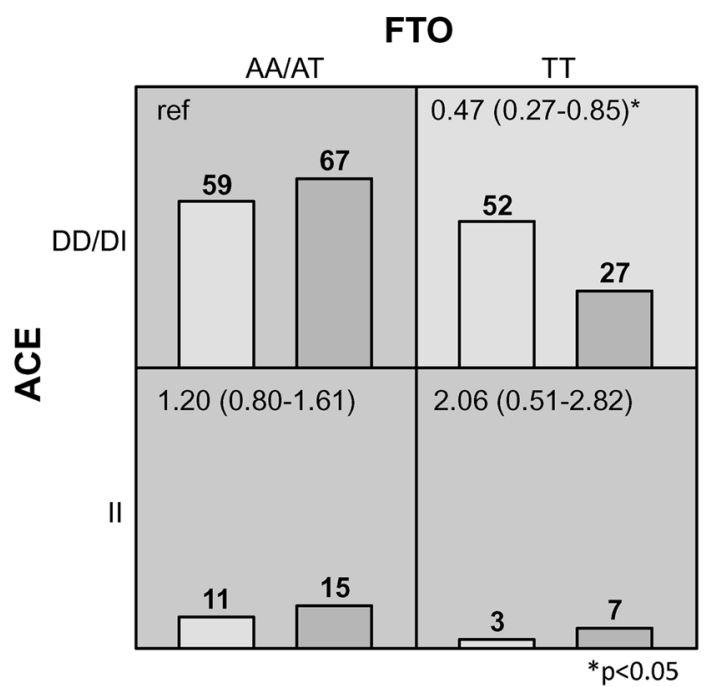

Fig. 3 Numbers of weight stable and weight gainers group in men for the different multi-locus genotypes of the best model obtained by multifactor dimensionality reduction (MDR) $(p=0.05)$. Dark gray cells indicate increased risk of weight gain. Light gray cells indicate decreased risk of weight gain, in each segment, the left bar indicates the number of weight stable subjects and the bar on the right the number of weight gainers. The odds ratio is shown in the left upper corner. ${ }^{*} p<0.05$

regression shows that men with the T/T genotype for FTO in combination with the D-allele for ACE were protected against weight gain (OR $0.47,95 \%$ CI $0.27-0.85, p=0.011$ ). In contrast, the TT genotype for FTO in combination with the II genotypes for ACE seemed to increase the risk of weight gain, though not statistically significant. No SNP-SNP interactions were found in women.

\section{Gene-dietary interaction}

We tested the possible contribution to the weight gain from the interactions of gene-dietary intake. However, we could not detect any significant contribution. The energy intake in women was $1.06 \times$ higher $(p=0.032)$ in the MMP2 $\mathrm{C} / \mathrm{C}-\mathrm{C} / \mathrm{G}$ versus $\mathrm{G} / \mathrm{G}$ carriers. This suggests that the MMP2 SNP works synergistically with energy intake on weight regulation.

\section{Discussion}

Here, we present a study of several gene polymorphisms in relation to weight gain over a longtime period. It should be noted that our study population is rather defined as being composed of a group that remain at normal weight over 10 years and a group that develops overweight during that period. We defined a weight gain of more than $8 \mathrm{~kg}$ over 10 years, as an obvious cutoff for weight gain. Because gender differences are regularly seen in matters of weight and weight regulation (Bradshaw et al. 2013; Heidema et al. 2010; Stevens et al. 2010), we decided to study men and women separately. Indeed we found sex-specific genetic associations. AKR1C2, ACE and FTO were associated with long-term weight gain in men, while MMP2 was associated with long-term weight gain in women over a 10 -year period. It should be noted that about $30 \%$ of the women passed the age of 50 during the 10-year period and therefore menopause might have affected weight gain. However, as we matched for age, the proportion was the same for the weight stable (39/127) and the weight gainers group (40/117) suggesting a minimal effect on our results.

AKR1C2 plays a role in the crosstalk between glucocorticoids and androgens as part of the regulation of adipogenesis and lipid accumulation (Veilleux et al. 2012). The androgen dihydrotestosterone (DHT) inhibits adipocyte differentiation in humans (Blouin et al. 2009b). Studies show that an increased expression or activation of AKR1C2 induces adipocyte differentiation by inactivating DHT (Blouin et al. 2009a; Veilleux et al. 2012). Previously, we found that AKR1C2 protein expression after weight loss/maintenance was increased and that the increase correlated with changes in parameters of adiposity including weight, BMI, waist and plasma LDL (Bouwman et al. 2009). Takahashi reported that the F46Y polymorphism (rs2854482) has a lowering effect on the enzyme activity (Takahashi et al. 2009). However, we did not find a genetic effect on weight gain, which might be explained by the low frequency of the T-allele in our population. In fact, only rs12249281 showed an association with long-term weight gain in men. This variation may have an influence via promoter activity of the AKR1C2 gene, but this requires confirmation in another cohort in addition to functional studies.

The Alu insertion/deletion (I/D) polymorphism in intron 16 of the ACE gene has been shown to be associated with body weight, BMI, overweight and obesity in various ethnic groups (Mao and Huang 2013). However, weight gain over a longer period has rarely been studied. Strazzullo et al. (2003) found that the DD genotype was associated with more spontaneous body weight gain and adiposity over 20 years in middle-aged men. Although in our study also an association between the ACE I/D polymorphism and weight gain was observed in men, it was the II-genotype that seems associated with long-term weight gain in men. Associations between ACE I/D and obesity parameters show the same controversy regarding the risk allele. For instance, in the study of Bienertova-Vasku et al. (2009), the II-genotype was found associated with the prevalence of obesity, whereas Settin et al. (2009) reported a significantly higher BMI in D-allele carriers. It has also been shown that subjects with the D/D genotype lose less 
body fat with similar amounts of weight loss than I-allele carriers (Hamada et al. 2011). It must be noted that rs4340 and rs1799752 are located in the same 288-bp insertion/ deletion. In fact, rs 1799752 is a 2-bp indel, compassing the 3 'nucleotides of the 288-bp indel of rs4340. It is also known that the ACE I/D polymorphism influences plasma ACE concentration and activity. D-allele carriers have a higher mean plasma ACE concentration than I-allele carriers (Rigat et al. 1990). Interestingly, a change in ACE plasma concentration during weight loss might predict the risk for weight regain (Wang et al. 2012). It is tempting to speculate that D-allele carriers can more easily reduce their plasma ACE levels during weight loss, which is favorable for weight maintenance and would be in line with our results. However, no evidence has shown whether such concentration change and eventually the risk for weight regain is associated with ACE genetic variation.

The FTO gene has been repeatedly reported for being associated with parameters of adiposity (Day and Loos 2011; Vimaleswaran et al. 2012). Here, we found that the A-allele conferred increased risk of weight gain over 10 years, but only in men. At the moment, we do not have a clear explanation for this sex difference. Interestingly, it has been shown that physical inactivity was associated with a BMI increase $\left(1.95 \pm 0.3 \mathrm{~kg} / \mathrm{m}^{2}\right)$ in homozygous A-allele carriers compared with homozygous T-allele carriers (Andreasen et al. 2008). The FTO genotype has also been shown to interact with weight loss (Delahanty et al. 2012), and the A-allele seems to complicate weight maintenance in severe obese patients (Woehning et al. 2013). Studies also show that the A-allele is associated with increased energy intake (Speakman et al. 2008), but this could not be confirmed in the present study. Alternatively, the FTO gene may be involved in the control of appetite as FTO expression is decreased in the hypothalamus of fasted mice when compared to fed mice (Stratigopoulos et al. 2008). Also, in humans, associations with appetite have been found (Karra et al. 2013). It suggests that genetic influence of FTO on long-term weight gain in men is not only a matter of physical activity or energy intake per se, but could follow another mechanism involving the brain.

In men, genetic interaction was observed between FTO and ACE (Fig. 3). This may point to fat storage/turnover capacity as the major process for long-term weight gain in men. In genetically obese diabetic mice, it was shown that ACE-inhibition blocks PAI-1 activity indicating that ACE is necessary for the formation of active PAI-1 (Zaman et al. 2001). ACE converts angiotensin I into angiotensin II, and in humans, angiotensin II increases the expression of PAI1, whereas inhibition of ACE decreases PAI-1 in plasma and tissues (Brown et al. 1998, 1999). In the mouse, inhibition of PAI-1 has been associated with reduced weight of fat depots and adipocyte size (Crandall et al. 2006). Influence of ACE on tissue plasminogen activator (tPA) has also been reported, but remains controversial (Brown et al. 1999). Overall, the adipose-specific reninangiotensin system appears involved in positive regulation of adiposity (Kalupahana and Moustaid-Moussa 2012). Mechanistically, ACE may influence adipocyte ECM dynamics which is an important cellular parameter of weight loss and weight regain. In this respect, we have proposed that the ECM has a lower metabolic plasticity than the cell, leading during weight loss to the accumulation of stress between the shrinking cell and the rigid ECM, which forms a driving force for weight regain because restorage of fat may alleviate this stress (Mariman 2011, 2012). The genetic interaction between FTO and ACE opens the possibility that also FTO may exert its effect somehow through the ECM dynamics.

Matrix metalloproteinases (MMPs) are essential for proper ECM remodeling (Bouloumie et al. 2001; Chavey et al. 2003). MMP2 is an endopeptidase that degrades the basement membrane surrounding adipocytes and thus may facilitate hypertrophic development of adipocytes and formation of adipocyte clusters (Brown et al. 1997). An induction of the MMP2 transcription in adipose tissue of obese mice and during human adipocyte differentiation has been reported (Chavey et al. 2003; Dubois et al. 2008). In this study, we found that the C-allele of MMP2 in women is associated with weight gain over a 10-year period, which is in line with a study of Han et al. (2008) who showed that the C-allele is associated with obesity. The polymorphism is located in a codon for glycine but is not accompanied by a change of this amino acid. Therefore, the biology behind the observed association remains unknown. Interestingly, a role for estrogens in the expression and activity of MMP2 has been proposed (Marin-Castano et al. 2003; Wingrove et al. 1998), which may explain the fact that the association was found only in women. Maybe, a different plasticity of the adipose tissue through MMP2 under increased energy intake can explain the difference in risk of long-term weight gain in women.

The interaction between genes and environmental factors, including nutrition and life style, can be a contribution to the long-term weight gain. Therefore, in the present study, we have also investigated the interaction of SNPs and macronutrient intake levels, but we have not detected any significant contribution for these SNPs. Our interaction results are in agreement with several reports for FTO and energy intake, fat, carbohydrate and protein (Lappalainen et al. 2012; Liu et al. 2010), but in contrast to other reports (Ahmad et al. 2011; Corella et al. 2011). An overview of interactions between FTO and environmental factors is given in supplementary Table 1 . No known interactions of environmental factors with the genes for AKR1C2, MMP2 
and TIMP4 have been reported. However, it cannot be excluded that other nutrients may play a role in the interaction with these SNPs in the long-term weight gain.

In a former study with a different cohort, we have investigated other genetic influences on weight gain over a period of almost 7 years (Heidema et al. 2010). CNTF was found associated with weight gain in men, whereas in women, IL6 appeared influencing long-term weight gain. Obviously, together with the present findings, this corroborates the concept that long-term weight regulation is influenced by genetic factors in a sex-specific manner. As a mechanism, the activity of the sympathetic nervous system was proposed, which has a strong effect on the balance between fat storage in and release from adipocytes. Our present results suggest ECM dynamics as a possible mechanistic factor working through this same balance of storage and release of fat in adipocytes.

All taken together, genetic association was found between SNPs in ACE, FTO and AKR1C2 and weight gain over 10 years in men, and between an SNP in MMP2 and weight gain over the same period in women. Our results indicate that the investigated SNPs in FTO and MMP2 contribute to the risk of long-term weight gain in men and women, respectively. Epistasis was observed for the SNPs in FTO and ACE in men. Further research can now be conducted to validate our findings concerning gender-specific genetic influences on long-term weight gain during adulthood.

Acknowledgments This research was supported by the Maastricht Proteomics Center of the Maastricht University. The authors thank the epidemiologists and fieldworkers of the Municipal Health Service in Doetinchem for their contribution to the data collection for this study. Logistic management was provided by J Steenbrink and P Vissink, and administrative support by EP van der Wolf. Data management was provided by A Blokstra, AWD van Kessel and PE Steinberger. The Doetinchem cohort study was financially supported by the National Institute for Public Health and the Environment and the Ministry of Health, Welfare and Sport of The Netherlands.

\section{References}

Ahmad T, Lee IM, Pare G, Chasman DI, Rose L, Ridker PM, Mora S (2011) Lifestyle interaction with fat mass and obesity-associated (FTO) genotype and risk of obesity in apparently healthy U.S. women. Diabetes Care 34:675-680. doi:10.2337/dc10-0948

Andreasen $\mathrm{CH}$ et al (2008) Low physical activity accentuates the effect of the FTO rs9939609 polymorphism on body fat accumulation. Diabetes 57:95-101. doi:10.2337/db07-0910

Arthur JW, Reichardt JK (2010) Modeling single nucleotide polymorphisms in the human AKR1C1 and AKR1C2 genes: implications for functional and genotyping analyses. PLoS ONE 5:e15604. doi:10.1371/journal.pone.0015604

Bienertova-Vasku J et al (2009) Effect of ID ACE gene polymorphism on dietary composition and obesity-related anthropometric parameters in the Czech adult population. Genes Nutr 4:207-213. doi:10.1007/s12263-009-0130-9
Blouin K, Blanchette S, Richard C, Dupont P, Luu-The V, Tchernof A (2005) Expression and activity of steroid aldoketoreductases $1 \mathrm{C}$ in omental adipose tissue are positive correlates of adiposity in women. Am J Physiol 288:E398-E404

Blouin K, Nadeau M, Mailloux J, Daris M, Lebel S, Luu-The V, Tchernof A (2009a) Pathways of adipose tissue androgen metabolism in women: depot differences and modulation by adipogenesis. Am J Physiol 296:E244-E255

Blouin K, Veilleux A, Luu-The V, Tchernof A (2009b) Androgen metabolism in adipose tissue: recent advances. Mol Cell Endocrinol 301:97-103

Bouloumie A, Sengenes C, Portolan G, Galitzky J, Lafontan M (2001) Adipocyte produces matrix metalloproteinases 2 and 9: involvement in adipose differentiation. Diabetes 50:2080-2086

Bouwman FG, Claessens M, van Baak MA, Noben JP, Wang P, Saris WH, Mariman EC (2009) The physiologic effects of caloric restriction are reflected in the in vivo adipocyte-enriched proteome of overweight/obese subjects. J Proteome Res 8:5532-5540

Bradshaw PT, Monda KL, Stevens J (2013) Metabolic syndrome in healthy obese, overweight, and normal weight individuals: the Atherosclerosis Risk in Communities Study. Obesity 21:203-209. doi:10.1002/oby.20248

Brown LM, Fox HL, Hazen SA, LaNoue KF, Rannels SR, Lynch CJ (1997) Role of the matrixin MMP-2 in multicellular organization of adipocytes cultured in basement membrane components. Am J Physiol 272:C937-C949

Brown NJ, Agirbasli MA, Williams GH, Litchfield WR, Vaughan DE (1998) Effect of activation and inhibition of the renin-angiotensin system on plasma PAI-1. Hypertension 32:965-971

Brown NJ, Agirbasli M, Vaughan DE (1999) Comparative effect of angiotensin-converting enzyme inhibition and angiotensin II type 1 receptor antagonism on plasma fibrinolytic balance in humans. Hypertension 34:285-290

Brug J et al (2012) Differences in weight status and energy-balance related behaviors among schoolchildren across Europe: the ENERGY-project. PLoS ONE 7:e34742. doi:10.1371/journal. pone. 0034742

Chavey C, Mari B, Monthouel MN, Bonnafous S, Anglard P, Van Obberghen E, Tartare-Deckert S (2003) Matrix metalloproteinases are differentially expressed in adipose tissue during obesity and modulate adipocyte differentiation. J Biol Chem 278:11888-11896. doi:10.1074/jbc.M209196200

Corella D et al (2011) A high intake of saturated fatty acids strengthens the association between the fat mass and obesityassociated gene and BMI. J Nutr 141:2219-2225. doi:10.3945/ jn. 111.143826

Crandall DL et al (2006) Modulation of adipose tissue development by pharmacological inhibition of PAI-1. Arterioscler Thromb Vasc Biol 26:2209-2215. doi:10.1161/01.ATV.0000235605. $51400.9 \mathrm{~d}$

Darimont C, Vassaux G, Ailhaud G, Negrel R (1994) Differentiation of preadipose cells: paracrine role of prostacyclin upon stimulation of adipose cells by angiotensin-II. Endocrinology 135:2030-2036

Day FR, Loos RJ (2011) Developments in obesity genetics in the era of genome-wide association studies. J Nutrigenet Nutrigenomics 4:222-238. doi:10.1159/000332158

Delahanty LM et al (2012) Genetic predictors of weight loss and weight regain after intensive lifestyle modification, metformin treatment, or standard care in the Diabetes Prevention Program. Diabetes Care 35:363-366. doi:10.2337/dc11-1328

den Hoed M, Westerterp-Plantenga MS, Bouwman FG, Mariman EC, Westerterp KR (2009) Postprandial responses in hunger and satiety are associated with the rs9939609 single nucleotide 
polymorphism in FTO. Am J Clin Nutr 90:1426-1432. doi:10. 3945/ajen.2009.28053

Dubois SG et al (2008) Potential role of increased matrix metalloproteinase-2 (MMP2) transcription in impaired adipogenesis in type 2 diabetes mellitus. Biochem Biophys Res Commun 367:725-728. doi:10.1016/j.bbrc.2007.12.180

Frayling TM et al (2007) A common variant in the FTO gene is associated with body mass index and predisposes to childhood and adult obesity. Science 316:889-894. doi:10.1126/science. 1141634

Hamada $\mathrm{T}$ et al (2011) Genetic polymorphisms of the reninangiotensin system and obesity-related metabolic changes in response to low-energy diets in obese women. Nutrition 27:34-39. doi:10.1016/j.nut.2009.10.012

Han DH, Kim SK, Kang S, Choe BK, Kim KS, Chung JH (2008) Matrix metallopeptidase 2 gene polymorphism is associated with obesity in Korean population Korean. J Physiol Pharmacol 12:125-129. doi:10.4196/kjpp.2008.12.3.125

Heidema AG, Feskens EJ, Doevendans PA, Ruven HJ, van Houwelingen HC, Mariman EC, Boer JM (2007) Analysis of multiple SNPs in genetic association studies: comparison of three multilocus methods to prioritize and select SNPs. Genet Epidemiol 31:910-921. doi:10.1002/gepi.20251

Heidema AG et al (2010) Sex-specific effects of CNTF, IL6 and UCP2 polymorphisms on weight gain. Physiol Behav 99:1-7. doi:10.1016/j.physbeh.2009.10.002

Johnson AD, Handsaker RE, Pulit SL, Nizzari MM, O'Donnell CJ, de Bakker PI (2008) SNAP: a web-based tool for identification and annotation of proxy SNPs using HapMap. Bioinformatics 24:2938-2939. doi:10.1093/bioinformatics/btn564

Kalupahana NS, Moustaid-Moussa N (2012) The renin-angiotensin system: a link between obesity, inflammation and insulin resistance. Obes Rev 13:136-149. doi:10.1111/j.1467-789X.2011.00942.x

Karra E et al (2013) A link between FTO, ghrelin, and impaired brain food-cue responsivity. J Clin Invest 123:3539-3551. doi:10. 1172/JCI44403

Koh WP, Yuan JM, Sun CL, van den Berg D, Seow A, Lee HP, Yu MC (2003) Angiotensin I-converting enzyme (ACE) gene polymorphism and breast cancer risk among Chinese women in Singapore. Cancer Res 63:573-578

Lappalainen T, Lindstrom J, Paananen J, Eriksson JG, Karhunen L, Tuomilehto J, Uusitupa M (2012) Association of the fat mass and obesity-associated (FTO) gene variant (rs9939609) with dietary intake in the Finnish Diabetes Prevention Study. Br J Nutr 108:1859-1865. doi:10.1017/S0007114511007410

Liu G et al (2010) FTO variant rs9939609 is associated with body mass index and waist circumference, but not with energy intake or physical activity in European- and African-American youth. BMC Med Genet 11:57. doi:10.1186/1471-2350-11-57

Lu Y et al (2008) Multiple genetic variants along candidate pathways influence plasma high-density lipoprotein cholesterol concentrations. J Lipid Res 49:2582-2589

Maclean PS, Bergouignan A, Cornier MA, Jackman MR (2011) Biology's response to dieting: the impetus for weight regain. Am J Physiol Regul Integr Comp Physiol 301:R581-R600. doi:10. 1152/ajpregu.00755.2010

Mao S, Huang S (2013) A meta-analysis of the association between angiotensin-converting enzyme insertion/deletion gene polymorphism and the risk of overweight/obesity. J Renin Angiotensin Aldosterone Syst. doi:10.1177/1470320313501218

Mariman EC (2011) An adipobiological model for weight regain after weight loss. Adipobiology 3:9-15

Mariman EC (2012) Human biology of weight maintenance after weight loss. J Nutrigenet Nutrigenomics 5:13-25. doi:10.1159/ 000337081
Marin-Castano ME et al (2003) Regulation of estrogen receptors and MMP-2 expression by estrogens in human retinal pigment epithelium. Invest Ophthalmol Vis Sci 44:50-59

Passaro A et al (2011) PPARgamma Pro12Ala and ACE ID polymorphisms are associated with BMI and fat distribution, but not metabolic syndrome. Cardiovasc Diabetol 10:112. doi:10.1186/1475-2840-10-112

Ragvin A et al (2010) Long-range gene regulation links genomic type 2 diabetes and obesity risk regions to HHEX, SOX4, and IRX3. Proc Natl Acad Sci USA 107:775-780. doi:10.1073/pnas.0911591107

Rigat B, Hubert C, Alhenc-Gelas F, Cambien F, Corvol P, Soubrier F (1990) An insertion/deletion polymorphism in the angiotensin I-converting enzyme gene accounting for half the variance of serum enzyme levels. J Clin Invest 86:1343-1346. doi:10.1172/JCI114844

Scuteri A et al (2007) Genome-wide association scan shows genetic variants in the FTO gene are associated with obesity-related traits. PLoS Genet 3:e115. doi:10.1371/journal.pgen.0030115

Settin AA, Algasham A, Dowaidar M, Ismail H (2009) Methylene tetrahydrofolate reductase and angiotensin converting enzyme gene polymorphisms related to overweight/obesity among Saudi subjects from Qassim Region. Dis Markers 27:97-102. doi:10. 3233/DMA-2009-0660

Smemo S et al (2014) Obesity-associated variants within FTO form long-range functional connections with IRX3. Nature 507:371-375. doi:10.1038/nature 13138

Sole X, Guino E, Valls J, Iniesta R, Moreno V (2006) SNPStats: a web tool for the analysis of association studies. Bioinformatics 22:1928-1929. doi:10.1093/bioinformatics/bt1268

Speakman JR, Rance KA, Johnstone AM (2008) Polymorphisms of the FTO gene are associated with variation in energy intake, but not energy expenditure. Obesity 16:1961-1965. doi:10.1038/ oby. 2008.318

Stevens J, Katz EG, Huxley RR (2010) Associations between gender, age and waist circumference. Eur J Clin Nutr 64:6-15. doi:10. 1038/ejen.2009.101

Stratigopoulos G et al (2008) Regulation of Fto/Ftm gene expression in mice and humans. Am J Physiol Regul Integr Comp Physiol 294:R1185-R1196. doi:10.1152/ajpregu.00839.2007

Strazzullo P et al (2003) Genetic variation in the renin-angiotensin system and abdominal adiposity in men: the Olivetti Prospective Heart Study. Ann Intern Med 138:17-23

Takahashi RH, Grigliatti TA, Reid RE, Riggs KW (2009) The effect of allelic variation in aldo-keto reductase $1 \mathrm{C} 2$ on the In vitro metabolism of dihydrotestosterone. J Pharmacol Exp Ther 329:1032-1039

van den Berg SW et al (2009) Genetic variations in regulatory pathways of fatty acid and glucose metabolism are associated with obesity phenotypes: a population-based cohort study. Int J Obes 33:1143-1152

Veilleux A et al (2012) Glucocorticoid-induced androgen inactivation by aldo-keto reductase $1 \mathrm{C} 2$ (AKR1C2) promotes adipogenesis in human preadipocytes. Am J Physiol. doi:10.1152/ajpendo. 00069.2011

Verschuren WM, Blokstra A, Picavet HS, Smit HA (2008) Cohort profile: the Doetinchem Cohort Study. Int J Epidemiol 37:1236-1241. doi:10.1093/ije/dym292

Vimaleswaran KS et al (2012) Association between FTO variant and change in body weight and its interaction with dietary factors: the DiOGenes study. Obesity. doi:10.1038/oby.2012.49

Wake DJ et al (2007) Intra-adipose sex steroid metabolism and body fat distribution in idiopathic human obesity. Clin Endocrinol $66: 440-446$

Wang P et al (2012) Circulating ACE is a predictor of weight loss maintenance not only in overweight and obese women, but also in men. Int J Obes. doi:10.1038/ijo.2011.278 
Wingrove CS, Garr E, Godsland IF, Stevenson JC (1998) 17betaoestradiol enhances release of matrix metalloproteinase-2 from human vascular smooth muscle cells. Biochim Biophys Acta 1406:169-174

Woehning A et al (2013) The A-allele of the common FTO gene variant rs9939609 complicates weight maintenance in severe obese patients. Int J Obes 37:135-139. doi:10.1038/ijo.2012.14
Wyatt SB, Winters KP, Dubbert PM (2006) Overweight and obesity: prevalence, consequences, and causes of a growing public health problem. Am J Med Sci 331:166-174

Zaman AK et al (2001) Angiotensin-converting enzyme inhibition attenuates hypofibrinolysis and reduces cardiac perivascular fibrosis in genetically obese diabetic mice. Circulation $103: 3123-3128$ 